\title{
The Bantu Element in Swahili Folklore
}

\section{Miss A. Werner}

To cite this article: Miss A. Werner (1909) The Bantu Element in Swahili Folklore, Folklore, 20:4, 432-456, DOI: 10.1080/0015587X.1909.9719900

To link to this article: http://dx.doi.org/10.1080/0015587X.1909.9719900

曲 Published online: 14 Feb 2012.

Submit your article to this journal

Џ Article views: 2

Q View related articles $\sqsubset$ 


\section{THE BANTU ELEMENT IN SWAHILI FOLKLORE.}

BY MISS $A$, WRRNER.

(Read at Meeting, May I9th, r9o9.)

"Ir must be remembered," says the late Bishop Steere, in the Preface to his Szwahili Tales (p. vi.), "that as a Swahili is by definition a man of mixed Negro and Arab descent, he has an equal right to tell tales of Arab and Negro origin."

The Arab element is so predominant in the collection just mentioned, and also in some others to which I shall have occasion to refer, that it would seem as if they would yield few items of interest bearing on genuine African culture.

The same impression is produced at first sight by the valuable compilation published in Germany under the title of Desturi za Waswahili (Customs of the Swahili). The constant intervention of the mwallimu,-with his chapter of the Koran to be read for every conceivable occurrence in life,-the formulas for charms and amulets. the marriage and funeral ceremonies, the rules of etiquette, and the chapters on education and law, are apt to suggest, on a casual survey, that the student of genuine Bantu custom will find little, if anything, to reward his study. However, on closer examination, we find the two elements persisting side by side, and, in many cases, - as has happened, mutatis mutandis, in other 
parts of the world,-traditional usages of immemorial antiquity may be figuring under Arabic names as accredited parts of Moslem ritual.

Before passing on to consider some of these points of custom, it may be well to make quite clear who the Waswahili are, for, in consequence of their extensive travels beyond the limits of their original territory, and the fact that their language is perhaps better known by name to Europeans than any other African tongue, there may be a little confusion in our notions on the subject. Of course, as we know, the word Swahili is not a national designation; it simply means "the coast people," being derived from the Arabic word for the coast, and therefore must have been first imposed by the Arabs. By what name the genuine, original Swahili, whose headquarters seem to have been the island of Pata and the adjacent coast near Lamu, called themselves before the settlements of the Persians and Arabs, I have hitherto been unable to find out. It occurs to me as just possible that Wa Shenzi, which now, in the mouths of the coast people, simply means "pagans," or "bush niggers," may have been a tribal name, as it seems difficult to get a satisfactory etymology for it in Swahili. Even if Krapf was right in spelling it Washinzi and deriving it from shinda, "to conquer," it would mean, not "the conquered," as he makes it, but "the conquerors." In his day it seems to have been used as a tribal name, and applied to the people now known as Wabondei. I In Desturi za IVaswahili, which is compiled entirely from trustworthy native accounts, we are informed that

"the meaning of "Waswahili" is "the people of the coast," and the sum of their customs is one from Amu (or Lamu) to Mvita (Mombasa) and from the beginning of the German coast, that is Tanga harbour, to Lindi."

48 disting again only means "those who live in the plain." Their language Is distinct from present-day Swahili, but they have to a great extent adopted
the latter. 


\section{The Bantu Element in Swahili Folklore.}

Their usages may differ slightly in detail, but on the whole they are the same, and they draw a clear distinction between themselves and the tribes inland of the narrow strip of coast to which they themselves are confined, these tribes being, in the north, the Wazegeju and Wadigo, and then, as we proceed southward, successively the Wazigula and Wabondei, Wadoe, Wazaramu, Wangindo, and Wayao. The Arab settlements along the east coast of Africa date from very early times. Whatever may be the truth about pre-Islamic settlements, the Sultanate of Kilwa was founded in the tenth century, and about the same time a Persian colony established itself at Lamu. (Sir H. H. Johnston places the arrival of the first Mohammedan colonists about A.D. 720.) The Arabs imported their religion, commerce, industries, arts, language, and literature, and, up to within the last fifty or sixty years, Arabic was the sole medium of culture accessible to the coast-dwellers. Swahili became a written language, (although the Arabic character is not perfectly adapted to it), and developed a literature of its own, and even a system of prosody, with results by no means contemptible, though of course Arabic was always looked upon as the vehicle of the higher scholarship. It is therefore natural that the Swahili language should abound in Arabic words, but its grammar has not been affected to so great an extent. It is true that it has lost many of its characteristic inflections, and that at Zanzibar the influx of Indians and other foreigners has tended to produce a very corrupt jargon; but the first English writer who mentions it, (Sir Thomas Herbert in 1677), fell into a grotesque misconception, perhaps not altogether extinct at the present day, when he called it "a mixture of Arabic and Portuguese." Even at Zanzibar, however, a distinction is drawn between good Swahili and that spoken in the bazaars, and the language spoken at Mombasa and Lamu is far less Arabicized. Moreover, it 
preserves expressions, lost at Zanzibar, which show its kinship with the other Bantu tongues.

It has sometimes been said that the admixture of Arab blood gives the Waswahili a great superiority over the African of an inland tribe. This I take leave to doubt. The opinion has gained currency, I fancy, on the authority of explorers who travelled with picked specimens of trained men (trained by experience under other Europeans), and whose standard of virtue and efficiency in details was largely determined by their personal requirements at the moment. Whatever the Arab descent in any given case may amount to,-and one fancies that it is often a negligible quantity, - the system of slavery by which it has been perpetuated must have tended to vitiate any advantages it might have been supposed to entail. I think, where a fair comparison is possible, the average Mnyanwezi, Yao, or Mnyanja compares very favourably with the average coast-man; and, while not undervaluing the elements of culture which the latter has carried far inland, to the shores of Lakes Nyasa and Tanganyika, it is generally found that the aborigines are decidedly the worse for contact with him.

Taking in the first place agricultural customs, we find an obscure passage which perhaps indicates that the reporter himself did not fully understand what he was describing:-

"They do not eat of the new crops except with mavumba. Many have spirits, such as the kinyamkera, the dungumaro, the shamigombe, and every kind of spirit. There are very few Waswahili who have no spirit. As people inherit property they inherit the family spirit too. And if a person who has a spirit eats without mavumba, by the evening he will get fever or some other sickness." (Desturi, p. 189.)

Mavumba is explained as "a particular kind of flour," which, presumably, is to be sprinkled over the firstfruits; but I own that this does not seem very satisfactory, and it seems much more probable that the real meaning has 


\section{The Bantu Element in Swahili Folklore.}

been forgotten. ${ }^{2}$ I think we have here a survival of the old Bantu harvest custom, by which no one was allowed to eat of the firstfruits before they had been tasted, with certain ceremonies, by the chief; a custom which, in its Zulu form (ukushwama), is fully described in the South African Folk-Lore Journal, (Nov., 1879, pp. 134-9). The custom described in the passage immediately preceding, which I now quote, would seem to have had a similar origin :-

"If a friend has come to see him,"-the owner of the field where mtama is being reaped,- " they break off for him a head of mtama, and it is beaten out, and (the grains) put on a plate and given him to eat, and when he goes away they break of three heads and give them to him as a present. And in like manner, at the rice harvest, if a friend comes along, a bunch of rice is broken off and a woman roasts it and it is given him to eat ..." Then follows, - "If a man gathers in much millet or rice, he makes an offering (sadaqa) to give to the poor,"-which, of course, is entirely Islamic.

Now, as to the spirits, to return to our first quotation, they sound mysterious enough, and I suspect that two entirely different things have been mixed up because they coincide in prescribing abstinence from something. In another part of the same book, a chapter is devoted to these same spirits, under the appellations above given, and many more; and the drummings, songs, and dances necessary for the expulsion of each one are detailed at length. Eacts of these spirits forbids the patient (through the practitioner called in) some kind of food; e.g., those possessed by the dungumaro may not eat mutton, and the shamngombe does not allow beef, while "those possessed by the kinyamker" must eat no fresh food without mavumba flour." As already stated, I cannot help thinking that this last is a confusion with the general prohibition of firstfruits. No doubt we have here to do with a genuine tabu, and indeed

"The dictionarics give vumba (or fumba), pl. ma., as "a lump of flour." 
we learn elsewhere that every family has some kind of meat, or some part of an animal, or certain fishes which its members are forbidden to eat, (the forbidden food being called mreiko or mzio). I hardly dare use the word totem, but I cannot help thinking that the kinyamkera, dungumaro, and the rest of them are nothing else but totems whose real meaning has been forgotten, though their hold is too strong for them to be got rid of altogether, and who, under the influence of Islam, have become mere sheitans to be exorcised with drums and dances." It may also be noted in passing that, when a growing girl's health gives her friends cause for anxiety, they try the effect of feeding her on her mwiko for a time.

The initiation ceremonies for young people of both sexes, though now including various Mohammedan features, have a strong Bantu element. We need only mention the manyago or unyago dance, in which a grotesque figure is constructed out of grass and leaves, and moved about by a man dancing inside it, to frighten the boys. Whether the bullroarer is used, I have not been able to discover, but a generation ago the Wanika, (the neighbours of the Waswahili inland from Mombasa), still used the mwanza friction-drum, the men and women having each their own, which the other sex is not allowed to see, (just as with the Nandi of the present day).

Before passing on to the folk-tales with which my paper is mainly concerned, I would mention one point more. It will be remembered that, in the Story of Liongo in Steere's Swahili Tales (p. 437), the hero can only be killed by being stabbed in a particular way with a copper needle. This reminds me of a story current among the Wadoe of a chief who could only be killed by being struck by the

\footnotetext{
"For mwiko being ascertained by a doctor, cf. Congo mpangu (p. 308, supra).

'It is glven in Dr. Velten's Safari na Waswahili, p. 179.
} 


\section{The Bantu Element in Swahili Folklore.}

stalk of a pumpkin, which was his mzio. I was told myself by some Nyasaland natives that the Yao chief Chikumbu was invulnerable, except by a splinter of bamboo,- - the case being put a little differently, as they said he had been charmed against everything else; and so, I believe, was Chibisa, who was shot with a sandbullet. $^{5}$

Coming now to the folk-tales, we find, as I have already said, that in the best-known collection, Steere's Swahili Tales, the Arab character decidedly predominates-indeed three of them, (as stated in Bishop Steere's Preface), actually occur in the Arabian Nights. There are, however, three which are certainly Bantu, and the others have mostly been Africanized by touches of local colour, etc., even where bits of African stories have not been worked into them. As all but three of these tales have been tabulated in the Folk-Lore Journal, (vol. vii., Appendix, pp. 59-80, 97-I10), I shall not linger over them further than to remark,-(I) that no one, so far as I am aware, seems to have pointed out that "The Story of the Washerman's Donkey" is evidently of Indian origin, being identical with the Sumsu" mara Jataka of "The Monkey who left his Heart in a Tree," (Folk-Lore Journal, vol. iii., p. I28-30), and (2) that "The Hare, the Hyrena, and the Lion," and "The Hare and the Lion," are only versions of well-known and widespread episodes in what M. Junod calls the "Roman du Liture." The former contains the incidents of planting gardens in partnership, and of the Hare entrapping the Lion, which, in this exact form, (that of getting him stuck fast in a narrow cave), I have met with in another instance, of which I have mislaid the reference. The incident of "Whoever stops, let him be eaten," does not seem to have much point; it may perhaps be a dim recollection of something better preserved in a Tete story collected by

'See The Natives of British Central Africa, p. 82, and Scott, Mang'anjo Dictionary, s.v. mankwala. 
Father V. d. Mohl, ${ }^{6}$ where the Hare, left in charge of the Lion's cubs, wrestles with one after another, making the condition that whoever falls shall be eaten. In "The Hare and the Lion" the first part of the story is not very close to its analogies elsewhere, but the Hare's request to be swung round by the tail, and the Tortoise's to be thrown into the mud, are recognisable in Uncle Remus; so is the Hare's stratagem for ascertaining whether any one is in his house, which is very like the trick by which Brer Rabbit tests the reality of Brer Fox's death.?

Since the publication of Swahili Tales, four other collections of Swahili stories have appeared,-Kibaraka (U.M.C.A., Zanzibar, 1885, 1896); Büttner's Anthologie der Suaheli Litteratur (Berlin, 1894), a German translation bound up with it being also issued separately as Lieder und Geschichten der Suaheli); Velten's Suahali Märchen (Berlin, 1898); and Prosa und Poesie der Suaheli (1907). A German edition of the Märchen was issued simultaneously; but of the Prosa una Poesie, so far as I know, no translation exists, though it is annotated in German. Some of the stories in Kibaraka have been issued separately, with an English translation as Swahili Stories from Arab Sources, which need not detain us. The rest of the stories badly need annotating, there being no indication whence, or from whom, they are derived, with the exception of two, published long ago in the South African Folk-Lore Journal. which are stated to have been told by a girl belonging to the Chipeta tribe, the A-Chipeta being identical with the Achewa, S.W. of Lake Nyasa, who are a branch of the Anyanja. (This points to another fact which must be borne in mind in considering Swahili folklore, viz. the number of slaves from different tribes who have been brought down to the coast in past generations, many of

\footnotetext{
"Transactions of the Berlin Oriental Seminary, 1902, Part ii, Afrikanische Studien.

"See also P. C. Smith, Annancy Stories, "Annancy and Chim.Chim," p. 9.
} 


\section{The Bantu Element in Srwahili Folklore.}

them being children, separated from their relatives, who, unless, as sometimes happens, they come in contact with a group of their own tribesmen, would speedily forget or confuse what they knew of their own traditions. This confusion would be increased in the island of Zanzibar, not only by Indian and other immigration, but by the settlement of contingents of freed slaves, mostly young, whom it was found impossible to return to their homes.) It would take us too long to discuss these stories in detail, but I have no doubt of the rain-making one being genuine Chewa, though I have not hitherto come across it ; it is not altogether clear as it stands, which points to its being imperfectly remembered. About the other, I am not so sure. It sounds like a reminiscence of the Ephesian Widow with the cynicism left out, and there are other stories which resemble it, without the highly satisfactory conclusion. Büttner has one of these, which is clearly of Mohammedan origin.

We will now briefly glance at the Hare stories in these four collections. It is well known what a prominent part the Hare plays in the folk-tales of Bantu Africa, which are so largely made up of animal stories. Bleek thought that the animal fables of the Hottentots and the märchen of the Zulus indicated a distinct and unalterable difference of culture and capacity; but the advance of research has placed this matter in a very different light. Not only are the stories whence "Brer Rabbit" is derived current among the undoubted Bantu tribes of the interior, but they exhibit a tendency to shade off imperceptibly into märchen with human actors. Hlakanyana is human, though abnormally human, yet it seems to me that the following sentences point to a transition stage, in which it was not quite clear whether he was looked on as an animal or a man :-

"Ucaijana (another name for Hlakanyana) is like the weasel; it is as though he was really of that genus; for, since he is called by the name of the weasel, it is as though he was of the same 
genus as it; his smallness is like its, and his cunning as great as its : he resembles it in all respects."

It will be remembered that many of Hlakanyana's adventures are identical with those attributed to the Hare. Many of the best-known stories are told, sometimes of animals, sometimes of human beings. The identification of Abu Nuwasi with the Hare is another curious point. Abu Nuwasi, we are told, was a real man: the dates of his birth and death $(762-815)$ are given, and he was a noted poet in his day and a favourite at the court of Harun al Raschid. He seems to have attracted to himself all the eccentric and not always edifying anecdotes current among the people in his own day and later; and these stories appear to have become very popular on the Swahili coast, judging from the number to be found in the four collections I have mentioned. One of them has reached Delagoa Bay, and is given in M. Junod's collection (Chants et Contes des Baronga), under the title of Bonawasi, which the editor quite excusably takes for a native's corruption of the Portuguese Bonifacio. Most if not all of $\mathrm{Abu}$ Nuwasi's adventures have come from Arabia; but I think that he has also acquired some which originally belonged to the Hare: in any case the Swahili are fond of calling the Hare, by a sort of pun, Kibwana Wazi, which might mean "the clever little master," though wazi properly means "open, clear, manifest." (It might, however, come from waza, "to think, ponder.") The usual word for the Hare is sungura,-Yao, sungula, corresponding to the Nyanja kalulu,-which is a real hare, though somewhat smaller than an English one, and not a rabbit. I do not understand why Schleicher, in the preface to his Afrikanische Petrefakten, should say that the sungura is the spring-hare or jerboa, (Pedetes caffer). In one of the Swahili Tales already referred to, the Hare is called not sungura, but kititi, probably as a kind of pet name, as it seems to mean simply "a little thing." 


\section{$44^{2}$ The Bantu Element in Swahili Folklore.}

We may take, in the first place, a story which is thus referred to in the Preface to Swahili Tales (p. viii):-

"There is a famous story of all the beasts agreeing to dig a well, and the Sungura alone refused to help. When it was finished, they watched in turn to prevent his getting water, but he cheated them all except the spider."

This is surely a mistake for the tortoise, as we shall see presently. The story is indeed a famous one, and much more widely distributed than Bishop Steere, writing in 1869 , could have any idea of. It seems to be found throughout Bantu Africa, and beyond its limits among the Hottentots, the Ehwe, and the Mandingo, -at least I think we may take "La Caverne des Animaux" in Monteil's Contes Soudanais as a variant of it. This tale is so well known that I need not linger over the variants. It is not included in the Swahili Tales, but two independent versions are given in Kibaraka. The first of them is called Hadithi ya Vinyama (the story of the animals). Here, after the other animals have failed, and the Hare has refused, the Tortoise succeeds in getting water, not by digging, but by singing, - no doubt a spell of some sort. The remarkable thing is that the other animals, including the elephant, have been trying unsuccessfully to get water in the same way, though, when summoning the Hare, they say,-." "Let him come that we may dig for water." Possibly there was some confusion when the story was dictated between the words imba (sing) and chimba (dig). There is a curious incident connected with the tortoise which I do not recall elsewhere, and I hardly know what to make of it.

"Then the Tortoise appeared, and the Elephant saw him and seized him and put him into his mouth; and he came out at his nose, and his companions said,-- "Let him go, perhaps he will get water," and they let him go. And he went, and sang, and got plenty of water." 


\section{The Bantu Element in Swahili Folklore. 443}

They leave the Elephant to guard the well, and the Hare comes up with some honey. The narrator quaintly says, oblivious of the circumstances,- "He knocked (at the door and cried) Hodi! and the Elephant answered, 'Come in !'" He gives him a taste of the honey, and promises him the rest, if he will consent to be tied up; he then eats the honey himself, fills his gourd at the well, and departs. The Buffalo then volunteers to guard the well, and meets with a similar experience. The Tortoise, who seems to have assumed the direction of affairs, then says,-- "Every time I station a person to watch the water, you let the Hare drink! To-morrow I will watch myself!" He does so, hiding in the water. The Hare comes, finds no one, draws water, and then bathes, and the Tortoise catches him and holds him fast till the other animals arrive. Here nothing further is said than that the Tortoise "held him," but in the parallel story to which I shall refer presently the passage runs thus :-

"(The Tortoise) got into the water and sat at the bottom. The Hare came, and cried,_- Hodil hodi/ the well! What is this? Is there no one here to-day? Very gaod, I will draw water l" He put in his right arm: the Tortoise seized it. The Hare cried out,- "Who are you? I don't want this water! I have water which is sweet,-let me go and you shall taste it!" But the Tortoise kept silence and held him tight. The Hare put down one leg, he put in both, and he seized him. He tried hard to get away, but the Tortoise held him fast" (hodari sana, i.e. very strongly).

It is a little difficult to see how the Tortoise could gather the Hare's members one by one into his mouth, which, so far as the story shows, was his only method of catching him, and keep a firm hold on them. In the original version, (though this is not expressly stated in all the variants), the Tortoise has previously covered his shell with some sticky substance. The Tete natives, in a story collected by Father V. d. Mohl, say "he took a great 


\section{The Bantu Element in Swahili Folklore.}

deal of wax on his back"; and in "The Rabbit and the Elephant," (Rattray's Some Folk-Lore Stories and Songs in Chinyanja, pp. 139-42), the Tortoise says,- "Never mind, stick bees' wax on me, I shall catch him on this very spot." This is a point of contact with the Tar-baby episode, which, indeed, in the Ehwe version of the tale, as given by Ellis," comes in here, though usually it occurs in a different connection. ${ }^{\circ}$

The well story in many cases ends by explaining how the Hare lost his tail. In the version before us it is apparent that this point has been lost sight of. It is true that, when the elephant catches him by the legs, and, being asked to seize him by the tail instead, obligingly does so, the Hare escapes, but it is made clear later on that he has not left his tail behind him. In fact, the closing incidents of the story read as if the narrator had not fully grasped the points at issue. I give them exactly as they stand :-

"He (the Elephant) seized him, and the Hare ran away, and they pursued him and he entered a burrow. The elephant came and put in his hand ${ }^{10}$ and seized his ear, and the Hare said,-." II has seized a leaf" ["Tu'n loose dat stump-root an' ketch hold et me!"]; and he seized his leg, [and the Hare cried out],"O-0-0-0-o! he has seized a tree!" And then he seized his tail and pulled him out. And he said,--My masters, you will kill me, but do not kill me at once; wait for me first till I fetch you some honey, -you stay here!" "

It seems almost incredible that the animals should have consented to this after all that had come and gone; but a

The Evie-steaking Peoples of the Slave Coast of West Africa, pp. 276-7.

"In passing, I may remark that I have come across two curious examples of the Tar-baby incident introduced into variants of the "Bird that made Milk." One of these is from Tete, where the hero is the IIare; the other is a Duala mairchen collected by IIerr Lederbogen, in which it is an edimo, - a apecies of goblin, - who is caught. Edimo is the same word as the Zulu isimu (cannibal, or rather ogre) and the Suto moctimlo, the same being occurs in Kikuyu stories under the name irimo.

${ }^{10}$ This sort of thing constantly occurs, - the narrator apparently forgetting that his characters are not in human shape. 


\section{The Bantu Element in Swahili Folklore. 445}

certain confiding simplicity is inherent in the African,-till it is abused once too often. "He went away to a distance and brought a jiwe la Manga," (literally "a stone of Arabia"; according to Steere it means "a piece of freestone"), and said to them,- "Open your mouths, the honey is coming!" He burnt them all up and they died; and there remained only he and the Tortoise, and they took all their gardens, and lived in peace and contentment," (raha mustarehe, a characteristic expression in Arabic). There is no reason why the "piece of freestone," (or, as Madan's Dictionary gives it, "whetstone "), should have burnt them, whatever other distressing symptoms it might have given rise to, but in a Nyanja tale of which I have a fragmentary version in MS. the Hare induces the Elephant to swallow a red-hot stone, a trick played on the Lion by the Jackal in one of the Hottentot stories collected by Bleek. The incident occurs in another form in a Kinga tale."1

The above story begins simply by saying "There were the beasts in the forest, and they were thirsty," but the variant referred to just now, which is entitled "The Hare and the Banana Tree," opens with the statement that "there was a Sultan and at his town there was no water." The parallel versions vary a good deal in this respect; some represent the Lion, or "the Chief," as giving orders to dig the well, and others merely assume a concerted action on the part of the "Animals." The incidents which follow are much the same as in the other version, though given in greater detail, except that the two successive guardians of the water are the Hyæna and the Lion, and that the latter actually springs on the Hare and seizes him before being beguiled with the honey. There is also the additional point that the Hare gives a reason for binding them,--that the honey is so strong that, unless tied to a tree, they will be unable to stand upright after eating it. Being caught, he is brought "Wakinga, W. Nyasa. 


\section{The Bantu Element in Srvahili Folklore.}

before the Sultan, who orders him to be burned. He says, - "Do not tie me with coco-nut rope, but with banana-leaves, and I shall die as soon as you throw me down in the sun." Green banana-leaves are meant, which would become very brittle after drying in the sun, and, accordingly, after lying still for seven hours, the Hare "stretched himself hard, so that the mgomba gave way, and ran away at full speed." This version preserves the incident which Uncle Remus renders as Brer Rabbit's request not to throw him into the briar-patch, and the other version the trick attributed to Brer Terrapin. In Dr. Velten's Prosa und Poesie der Suaheli, we have a third version, in which far more of the original character is lost. This is called "The Story of the Chief and the Hare." "The people and the animals of the forest" are summoned to dig wells in time of drought; the Hare refuses, and is debarred from drawing water. A succession of men are stationed to guard the well, all of whom are induced by fair words to let the Hare pass. Then the chief says,- "Now I will send the beasts of the forest." The lion tries, and is beguiled; then a girl volunteers, and is successful one day, but on the next the Hare comes back and overcomes her resistance with his winning ways, and the girl is dismissed. Finally he is caught by the Crab, who holds him fast by the tail. When taken before the chief he asks to be tied with green palm-branches and laid in the sun, with the result already described.12

I will now glance very shortly at the remaining animal stories in these three collections. "The Hare and the Kite" in Kibaraka is partly identical with "Le chacal, la colombe, et la panthere" in Jacottet's collection of Suto tales, and "The Dove and the Heron" in Bleek's Reynard

${ }^{39}$ Captain Barrett has collected a variant of this tale, containing the incident of the banana-leaves, among the Wa-Sania, a tribe, whose origin is at present uncertain, living some distance to the north-west of Mombasa. 
the Fox in South Africa (p. 2r). The Hare frightens the Dove into giving him her young ones, as the Jackal does in the other stories, till warned by the Kite; but, whereas the Jackal kills the Heron in one version and maims him in the other, the Hare does not succeed in catching the Kite, and the stratagem he employs is different from the Jackal's. He lies on the ash-heap, and pretends to be dead. The Kite, not completely satisfied, employs a stratagem to make sure, remarking aloud that "the ancients have said that, if a Hare is really and truly dead, he wags his tail." The Hare falls into the trap,-like Brer Fox when he hears that "when a man go ter see dead folks, dead folks allus raises up deir behime leg an' hollers wahoo!", and the Kite escapes.

We have, further, three versions of the very common story in which the Hare and the Hyrna (or some other animal) enter into partnership and start on a journey. In the complete form, the Hyana, being the stronger, tyrannises over the Hare, who, by his superior cunning, gets the better of him in the end. In Macdonald's Africana, ${ }^{13}$ there is a Yao version of this story. I have an incomplete MS, one of a Chinyanja variant, where the Dzimwe " is substituted for the Hyana. But it would take too long to enumerate all which are extant. Büttner substitutes the Mongoose (cheche) for the Hyana, and it ends up with his being caught cheating, whereupon the two fall to fighting and pull each other's ears off, which they exchange. This is why the Hare has long ears and the Mongoose short ones, as formerly the reverse was the case. I have never met any other example of the story in exactly this form. A closer parallel, fairly complete, is given by Dr. Velten, (Prosa und Poesie, p. 51 , "Geschichte

\footnotetext{
${ }^{13} V_{0 l}$ ii., p. 327.

"The Dzimwe is sometimes called an elephant and looked on as such, but it is more probably a being of the ogre species; cf. The Natives of British Concral Africa, p. 233 .
} 


\section{The Bantu Element in Swahili Folklore.}

vom Hasen und der Hyäna"). I cannot now examine these versions in detail, as I wish to say a few words about two or three märchen in this collection which seem to me highly curious.

The first of these is to be found in Kibaraka, under the title of "The Story of the Children and the Zimwi." Zimwi is evidently the same word as the Zulu izimu and Suto modimo,-which are usually translated "cannibal"; but which, as is plain from some fairly wellknown stories, implies something more than a mere human anthropophagist, the amazimu being in some respects preternatural, but also preternaturally stupid, like our northern giants. A Blantyre native whom I asked for an explanation of the Dzinwe could get no further than that it was a creature in a story; another native, at Likoma, wrote that the word means "sometimes an elephant, sometimes an evil spirit." The Arabicized Swahili consider it to be equivalent to jini. The first part of the story is very similar to the Suto "Tselane," to "The Child in the Drum" (given by Mr. D. Kidd in Savagt Childhood), to Dr. McCall Theal's "The Cannibal Bird," and to a Duala variant collected by Herr Lederbogen, not to mention others; while the opening has touches which localise it on the coast, and the words sung by the child are, so far as I can make anything of them, Yao. The end is one I do not remember in any story of this type, but it has an interesting resemblance which I shall note presently.

"Some children went to a river to look for cowries. One found one cowry, and laid it on a rock. And they searched and found and went home; but that child forgot his shell, and, as it was a very fine one, he asked his companions to go back with him and fetch it. They said,- "Go and fetch it, and we will wait for you," and he went and sang :-

Cheche cheche chambalamanda. Little by little it has dawned; Ngala jangu naliwele. My shell, I have forgotten it. 


\section{The Bantu Element in Swahili Folklore. 449}

Nati mbuje ngatole.

Krosimama andamilile.

I said, I will go back and fetch it. Wati lutumbo kuchukuchu.

There they stood all in a row (?)

My inside said "kuchukuchu" (?)

And he found a zimzei sitting on the rock, who said to him,"What do you want?", and the child sang (in answer), and the simrei said, - "I cannot hear, come closer." And, when the child came near, he took him and put him into a cask and carried him off. And as he went he came on some people sitting in the daraza, (as we might say, 'on the village green'), and he said to them, - "I have my drum; I want a fowl and rice that I may eat." They said,- "Sing," and the child sang. The zimwi was given food, and he ate, but he gave none to the child, he ate it all himself. He went to the boy's own village, and the people (there $)$ said, - "We have heard that you, Zimwi, have a very fine drum, sing for us!" And he said,- "I want beer." And the child sang, and all the people (knew his voice and) said,-_ "This is our child." They gave the simwi beer, and he got drunk and went to sleep. Then the people went and took his drum, and found the child and carried him off and hid him in the inner compartment of the hut, and into the drum they put snakes and bees and biting ants, and fastened it up as it was before. And they went and awakened him, and said,--"Zimwi, wake up I some people have come and want to hear your drum." He took his drum and beat it, and heard (lit.) silence; he did not hear the child's voice. So he Went his way, and on the road he opened it and found a snake, and it bit him, and he died. Where he died there sprang up Pumpkins and cucumbers, and some children came that way and said,- " These pumpkins are fine; let us go and get father's sword and cut them open" (lit. strike them). One pumpkin got angry and pursued those children, and they ran away till they came to a river, and they saw an old man there, and said,- "Eh! father, Please ferry us over to the other side, we are running away from a pumpkin." The old man ferried them across and they ran till they came to another village, where they found plenty of people sitting in the baraza and said to them,- "Hide us from that pumpkin: the simwi has turned into a pumpkin, so do you take it and burn it in the fire." The pumpkin arrived, and said,-"Have you seen my people who have run away?" The people said,- "What sort 


\section{The Bantu Element in Srvahili Folklore.}

of people are yours? We do not know them." But it said,"You have shut them up inside." And they took the pumpkin and threw it into a big fire, and it was burnt up so that only ashes were left, and they threw them away. So they let out the children, who then went home to their mothers." 15

In a Shambala story, ${ }^{16}$ which is a curious variant of the "Swallow myth" exemplified in Casalis' Kammapa at Litaolane, some children playing in the fields see a huge gourd and remark on its size, which seems to offend it, for it replies,-_" Pluck me, and I will pluck you." The parents refuse to believe the story, and the gourd continues to grow till it is "as large as a house," swallows the whole population of the village, except one woman, and retires into a lake. The woman has a son who grows up, kills the pumpkin by shooting it with arrows,--(it roared, "so that they could hear it at Vuga "),- - and then cuts it open and lets the people out. Of course there is no trace of the swallowing in the zimwi story, but the notion of the gourd or pumpkin in this connection is curious.

I must content myself with a bare mention of another story, which is interesting from several points of view,-" "The Husband who was a Jinn" (Mume jini),-and pass on to ${ }^{2}$ märchen in Dr. Velten's earlier collection, which has the title "Sermala na Hirizi" (the Carpenter and the Amulet). Both these words are Arabic, and, if the story stood alone, we might conclude that the whole of it had a like origin, but I think we shall find on examination that this is not the case. The translation in full is :-

"There was once a carpenter named Makame, whose work was to cut logs into shape. He went away into the bush and shaped

${ }^{18}$ Cf. P. C. Sunth, Annancy Stories, "Ticky-Hicky Boom-Boom," p. 62.

${ }^{1 "}$ Seidel, Ceschichten und Lieder der Afrikaner, p. 174. It is also given in Basec's Contes lofulaires d'Ajrique, p. 297. This is in many respects a most useful collection; hut it must be pointed out that its classification of Bantu tribet is not always accurate. Nos. 144 and 115 , given as "Loumbo," are really Yyo, and should, as such, have been placed under LX., while LXII. and L X ("Nyassa" and "Chinyanja or Mang'anja") are identical. Otji-ILerero and Ova-Herero have likewise lieen wrongly placed under two separate headings" 
a mvinja (casurina) tree into a figure like a human being, with fingers, ears, nose, eyes, mouth, and chin. And he called a mwallim to read (the Koran) over it, and it was turned into a person. And he called a weaver, and he wove a cloth for it, and he took it away to his house, It was a very beautiful woman,there was no other like her. And her owner Makame hid her in the bush, and many people passed by and saw her, and carried off that woman. And when Makame returned with his loads of logs, he looked for his wife in that place, and she was not there. And Makame cried, and came home to his village and stayed there in his house. And the woman, in the place to which she was taken, did not speak with her mouth, - she stayed just like a dumb person. And they said to her, - "How is it, you woman, that you do not speak?" And she said nothing. Many people came, and reasoned with her, and tried to persuade her, but she still kept silence. She did not speak, neither did she laugh or show herself pleased. And Makame sought for his wife, whom he had cut out of a tree, and the woman sought for some one who could find out her husband and give him back to her; and Makame went to the place where his wife was, and when he saw her he recognized her, and said,-_"This is my wife." And he said to those people,"He who does not know the meaning is not told the meaning, for I want this woman who does not speak. Perhaps she has been stolen and is grieving for her husband, and that is why she does not speak. I want that we should draw up an agreement to the following effect,-If she does not speak, my head shall be forfeit to you; if she speaks, she is my own wife." And they drew up a contract, and each person kept his own (copy). And Makame went and sat down on a seat, and the woman was sitting in a place apart. And where Makame sat, there was a bird which is called asiraji. And Makame said to this bird,- "My father called a carpenter (and told him) to hew a tree into the likeness of a child of Adam, to make it in every way like a human being. And there came a mwallim and read over it and put an amulet (hirizi) on it, and it was turned into a person who can talk and laugh. And there came a weaver and wove cloth for it. Now, you, asiraji, (tell me) which of these three men is the owner of the woman?" And the asiraji was silent,-how should he 


\section{The Bantu Element in Swahili Folklore.}

answer ?-he is a bird. But the man was not speaking to the asiraji, he was speaking to his wife. Makame was angry, and said,- "You, asiraji, I will beat you ;-tell me truly which of these three men is the owner of the woman." And he rose up, and was going to strike the bird, when the woman said,- "Leave him alone, master, - why should you strike this bird?" And as soon as the woman had spoken, the people were astonished. And Makame took his wife home to his village, and lived with het many days. One day he said to her,- "Wife, I am going up country to trade." And he said,- " The sultan of this country is a very profligate man who kidnaps men's wives. Do you keep quiet and stay in your house." And Makame started and went his ways up country to trade, and his wife remained behind. One day a slave-lad of the sultan came and entered Makame's house, and asked for fire. And he was told,- "Go on into the upper room," and he went up. And when that lad saw Makame's wife he fell down (with astonishment). And he went to his master, and said,--"Master, I have seen a very beautiful woman in Makame's house,-your wife is very ugly compared with Makame's wife." And the sultan said-" Is it true?" And he said,- "It is true, sir." The sultan sent an old woman to Makame's house, who persuaded his wife to come away with her, and said to her,"The sultan will give you many clothes of silver and vessels of gold, and you will be a great person." And she went to the sultan's house and stayed there, and he was her husband, and as for Makame's house she forgot it altogether, (literally, she cast it far away from her). And when Makame came back, he cried "hodi" at the door of his house, and found everything silent, and said,"Perhaps she has gone to my mother's, - her mother-in-law's." And he went to his mother's house, and asked if his wife were there, and his mother said, - "She is not." And Makame went his way home, and entered his house, and thought,- "The sultan has taken away my wife." And he said,-_. "Never mind." And he called a bird whose name is kurumbiza, and said,--"Go to the sultan's house,-I, Makame, send you to bring back my things: if you get them, we will share them equally, you and I." $\Lambda$ nd the bird went to the sultan's house, and sat on the roof and sang its song, saying,- 


\section{The Bantu Element in Swahili Folklore. 453}

"I do not eat the fruit of the tree.

Do you (i.e. the sultan) take her, - I do not want her.

Put on her anklets and neck-ornaments and a bead girdle." "

This song is not very easy to translate, as is often the case with songs. The first line is, literally, "I do not eat the tree the fruit." Dr. Velten, probably following an explanation given by his informant, says that this is an allusion to the wife being carved out of wood. The words translated "I do not want (her)" (si wajawaja) and "bead girdle" (tunda) are not in any dictionary I have been able to consult, and I have been obliged to depend on Dr. Velten for the above renderings. The bead girdle refersed to is the one worn by women of most, if not all, Eastern Bantu tribes under their other clothing. I should imagine that it was in the first instance a protective charm; it is now a convenient way of carrying about one's personal property.

"The woman said, -

"Take these,

Take Makame's things,

Makame is not my husband.

He does not want the things. He wants me myself."

And she gave him all his things, -chains, and anklets, and rings, and cloth, everything which women wear, and she gave them to Makame. And that bird took them to him, and said, - "Here are your things, Makame. I have brought them all." Makame said, - "My things have not yet come. You have forgotten one thing. Go again." And the bird went again, and sang as before, and the woman answered as before. And she said,- "I have given you your things, what more do you want?" And she cried bitterly, and her husband the sultan came, and said to her,"Why do you weep, my wife? Give Makame his things. And if it is that amulet, give him that too. I have plenty of amulets here, whether of magic ( $z a$ uchawi) or silver or gold (ornaments), take them and put them on,-what is Makame's amulet?" And he took it from her by force, and gave it to the bird, and immediately there sprang up a mvinja tree, (i.e. whe was turned into one). 


\section{The Bantu Element in Swahili Folklore.}

And the sultan was quite confounded. And Makame stayed at home, and this is the end of the story."

It is obvious that this tale contains many exotic elements, and, did it stand alone, we might perhaps set it down as of non-African origin. But the two variants with which I am acquainted seem to suggest that it may have a Bantu original which in this form has been overlaid with Arabic accretions. One of these variants is that given by M. Jacottet in Litudes sur les langues du Haut Zambize, under the title "Le lievre et sa femme." Here it is the Hare, not a man, who makes himself a wife out of a log of wood. The process of giving life to the figure is not detailed. The chief hears of the woman from some of his people who pass through the village, and sends to fetch her in her husband's absence. The Hare comes home and finds her gone. He gets a drum and goes to the chief's place, beating it and singing,-

\section{"Ndindil ndindil ka ndindi "g'oma \\ Ka ndindi ng'omaka ndindi ng'oma !" \\ (They have taken away my wife! \\ She was changed back into a log of wood.)}

The other story is one which I obtained in 1894 at Ntumbi in Nyasaland. It is unfortunately very short, and probably imperfect, but quite recognisable in its main features. It was published in the (now defunct) Zeitschrift für Afrikanische und Ozeanische Sprachen (Vol. III., No. A' 1897), and M. Jacottet refers to it in the work already mentioned as being identical with the story just quoted. I am not quite certain of the provenance of this story. The district where it was obtained is pretty far inland, being some thirty miles west of the Shire river and at the foot of the Kirk mountains, but the population is very much mixed, and the girl who related it to me is the daughter of a Nyanja (or possibly Chewa) father and a Yao mother. Now, as these tales are usually handed on 
by the women, Mbuya had probably heard it from her mother, and in that case it had come from the Shire Highlands, or perhaps still further east. This suggests the possibility of its having an Arab origin after all, the Yaos having for many years been in touch with the Moslems of the coast, many of them indeed making profession of Mohammedanism. Their caravans, conveying either slaves or more legitimate merchandise, were constantly journeying up and down, and there are several stories extant in Yao which are Arab tales altered almost beyond recognition. Still I cannot help thinking that $M$. Jacottet's version and the one I am about to give show the original form, and, hoping that a fuller form may yet be recovered, $I$ give the following translation of the tale as I received it:-

"A frog adzed a woman out of (the trunk of) a tree, and made her his wife, And he put a mpande on her heart. The chief took his wife away from him; - her name was Njali, the wife of the frog. The chief took her away from him. And he (the frog) sent a wild pigeon to fetch the mpande, and she" (the text does not show whether the chief or the wife is meant, but a comparison with the Swahili variant suggests the latter), - "refused. And the (pigeon) returned, and he sent it again, and it went. And it brought the mpande, and the woman died; and she was changed into a kachere tree, that woman, she was changed into a tree. It (the story) is finished."

A mpande is a disc about the size of a half-crown, cut from the flat part of a large sea-shell and greatly valued as an ornament or a charm, or both, by the inland tribes. 1 have only seen them once or twice worn by men, on thongs or bangles attached below the knee. I can find no other instance of this object figuring as a life-token, but Mr. Barnes says that at Kotakota the word means an "operculum, worn as a charm." Those I saw did not look like opercula, but were evidently the top of a spiral shell 


\section{The Bantu Element in Swahili Folklore.}

cut or ground flat.17 In the tale of Makame the mpandt has become an ordinary amulet, designated by its Arabic name of hirizi, just as the figure is brought to life by the mwallim "reading over it." The verb somea used in this sense always, I believe, implies the Koran, which appears to be known on the Swahili coast chiefly as a grimoire. I have not been able to identify the bird called kurumbisa, which Makame sends to fetch the amulet. Krapf says that it is "a bird which sings a long and curious tune," and adds that it is called jupi in the Mrima dialect. On turning up jupi, we find a vague suggestion that it may be "an ousel," which does not help matters much. The reduplication of the main incident is worth noting; it incorporates a very faint recollection of another story which occurs in M. Junod's collection as "Les Trois Vaisseaux" and in Dr. Velten's as "The Bride of the Three Brothers." There is no trace of the bird in the Subiya version, where the Hare goes himself to the chief's kraal, beating his drum as he goes. I have only space to note in conclusion that Dr. Velten's Prosa und Poesif, contains Hadithi ya Kigwe ("The Story of a String," i.e. the story of an amulet), which combines this motive with a different one,-probably Arab and found in a story given by Büttner under the title "What sort of people women are,"-in which a dead wife, brought back to life by her husband's devotion, denies all knowledge of him.

\section{A. WERNER.}

17 I think that the kind I mean is a cone-shell. I may add here that an old woman I knew in the same district used to wear round her neck an ivory object which she called "moyo wanga" (my life), and which no persuasios? would induce her to part with. It was no doubt an ordinary protective amulet, but I have never seen another like it; it was a hollow peg of ivory about three inches long, the upper end pierced for strings, and shaped something like a curved ninepin. 